\title{
SIMULASI STRATIGRAFI SINTETIK PADA SISTEM CEKUNGAN SEDIMEN MENGGUNAKAN PERSAMAAN DIFUSI
}

\author{
Syaiful Alam \\ Program Studi Teknik Geologi, Fakultas Teknik Geologi, Universitas Padjadjaran \\ e-mail : syaiful.alam@unpad.ac.id
}

\begin{abstract}
Abstrak. Persamaan difusi telah disimulasikan untuk mengetahui gambaran stratigrafi pengisian suatu cekungan. Simulasi tersebut memodelkan proses erosi dan pengendapan material sedimen per waktu. Parameter yang digunakan berupa initial input dan boundary condition yang sederhana, yaitu dengan asumsi fluktuasi sea-level dan laju subsiden yang stasioner serta geometri cekungan yang simetris. Kondisi serupa dan identik dapat ditemukan pada cekungan danau purba, yaitu Cekungan Bandung, yang digunakan sebagai data lapangan untuk menguji ke-robust-an metode ini. Kombinasi aturan transportasi sedimen dengan kontinyuitas masa pada suatu gradien slope menunjukkan linearitas antara laju perubahan elevasi dengan sediment flux pada suatu cekungan. Semakin tinggi laju erosi, maka semakin berpotensi suatu batuan dasar cekungan untuk tersingkap.
\end{abstract}

Kata Kunci: Stratigrafi sintetik; persamaan difusi; cekungan sedimen

\begin{abstract}
The diffusion equation has been simulated to have a grip of stratigraphic basin-filling. The simulation models the process of erosion and deposition of sediment through time. The parameters used are simple initial input and boundary condition, assuming the stationary of sea-level fluctuation and rate of subsidence and also symmetrical basin geometry. Similar and identical conditions can be found in prehistoric lake basins, the Bandung Basin, used as field data to test the robustness of this method. The combination of sediment transport rules with continuity of mass on a slope gradient shows the linearity relationship between the rate of elevation change and the sediment flux in a basin. The higher rate of erosion, the more potential a bedrock of a basin to be exposed.
\end{abstract}

Keywords: Synthetic stratigraphy; diffusion equation; sedimentary basin.

\section{PENDAHULUAN}

Kegiatan eksplorasi hidrokarbon umumnya menargetkan structural trap dibandingkan stratigraphic trap karena tingkat resiko dan kebutuhan resolusi yang tinggi, sehingga sampai saat ini tidak terlalu banyak penelitian dan discovery pada stratigraphic trap (Alam dan Setiadi, 2019; Nayoan, 1981; Stirling dkk., 2017; Zanella dan Collard, 2017). Beberapa lapangan yang memiliki potensi stratigraphic trap namun masih bersifat unexplored potential adalah Asahan Offshore dan Cekungan Biliton yang merupakan Paleogene Play serta future potential pada sedimen Tersier (Atkinson dkk., 2006; Muchlis dan Elders, 2020; Suwondo dkk., 2019). Analisis cekungan menjadi bagian yang tidak terpisahkan dalam tahapan eksplorasi hidrokarbon. Setidaknya, terdapat dua konsep yang harus dipahami untuk menganalisis cekungan, yaitu basinforming dan basin-filling. Tektonik meliputi basinforming, sehingga suatu cekungan dapat terbentuk oleh asosiasi deformasi lithospheric stretching, flexure, ataupun strike-slip (Cloetingh dan Burov, 2011; Noda, 2013). Stratigrafi berperan dalam memahami mekanisme basin-filling yang dipengaruhi oleh faktor internal dan eksternal. Faktor eksternal yaitu fluktuasi muka-air laut, iklim, dan subsiden. Sedangkan avulsion, channel migration, dan switching delta-lobe merupakan proses akibat faktor internal yang berlangsung dalam suatu cekungan.

Dalam perkembangannya, eksperimen stratigrafi sintetik untuk transportasi sedimen memiliki banyak penerapan, seperti pada kasus pengendapan dan transportasi sedimen klastika (Kaufman dkk., 1991), model difusi multi-litologi (D Granjeon dan Phillip, 1999; Didier Granjeon, 2014). Contoh lainnya adalah simulasi dinamika material sedimen yang bergerak pada suatu lereng dengan algoritma depth-dependent diffusion (Rivenaes, 1992). Makalah ini menggunakan kombinasi dua 


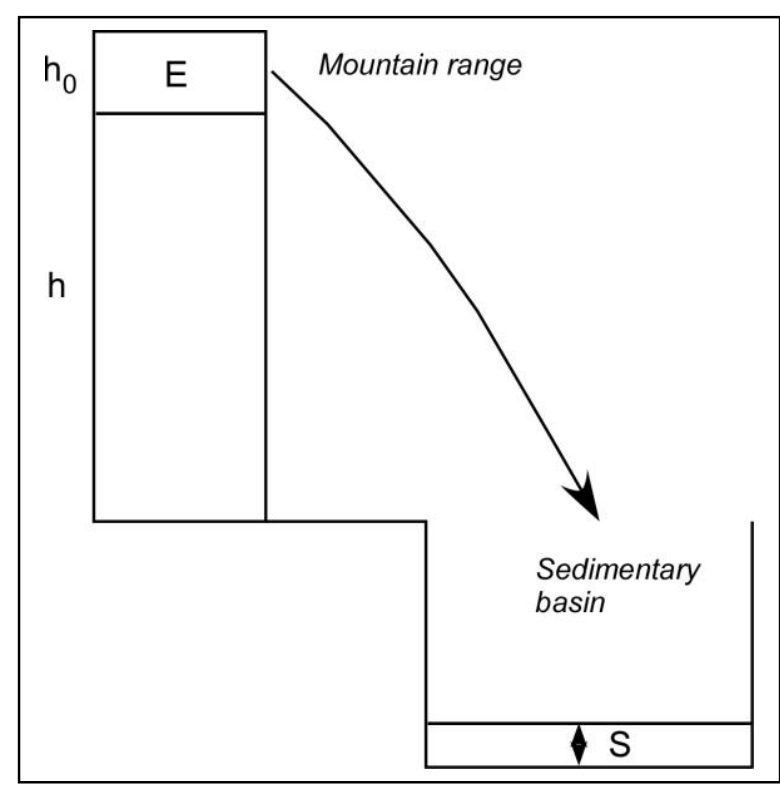

Gambar 1. Ilustrasi perpindahan masa sedimen

persamaan, yaitu persamaan Exner untuk kesetimbangan masa sedimen dan transportasi sedimen yang melintasi gradient slope, serta laju fluktuasi sea-level dan subsiden yang diasumsikan stasioner.

\section{METODOLOGI}

Konsep difusi telah lama diterapkan pada problem-problem spesifik keteknikan, misalnya transportasi sedimen, pembuangan limbah, transfer panas, dan problem turbulensi (Brush, 1962). Cekungan sedimen pada akan menerima pasokan sedimen dari suatu sumber (dapat pula berupa rangkaian pegunungan) yang akan terus dikikis oleh erosi yang terus menerus. Fenomena fisik ini jelas merupakan perpindahan masa partikel sedimen dari suatu tempat (Hawie dkk., 2019; Schwarzacher, 1975), sehingga dapat dimodelkan setidaknya secara deterministik.

Ketebalan sejumlah material sedimen $S_{t}$ yang terendapkan di cekungan merupakan hasil erosi $E_{t}$ dari suatu ketinggian $h_{0}$ pada suatu waktu $t$ secara sederhana memiliki hubungan $S_{t}=k E_{t}$ dengan $k$ merupakan konstanta yang mengekspresikan area dan jarak yang relatif antara sedimentary basin dan mountain range seperti pada Gambar 1. Adanya perbedaan elevasi $\Delta h$ dan jarak $\Delta r$ antara mountain range dengan sedimentary basin menyebabkan adanya suatu gradien lereng sehingga material sedimen dapat berpindah melalui aturan mekanisme transportasi yang dapat diformulasikan sebagai berikut:

$$
S(r)=-k^{\Delta h} / \Delta r
$$

Persamaan (1) menggambarkan transportasi material sedimen menuruni suatu lereng mountain range yang sebanding dengan gradien lokal, semakin curam suatu slope maka semakin banyak material sedimen yang tererosi.

Material sedimen yang bergerak tentunya berinteraksi dengan batuan dasar (bedrock) dan dengan fluida. Evolusi interaksi tersebut tertuang dalam prinsip kesetimbangan masa sedimen (mass continuity) yang dikenal dengan Persamaan Exner. Persamaan tersebut diperkenalkan oleh Felix Exner, yang merupakan Meteorologist Viennese (Paola dan Voller, 2005). Persamaan Exner berkembang dari kelompok riset morfodinamika yang melibatkan adanya pengaruh subsiden, tectonic uplift, kompaksi dan presipitasi pada suatu transportasi sedimen sehingga menyebabkan adanya perubahan elevasi per waktu akibat interaksi faktor-faktor tersebut. Penerapan transportasi sedimen dari suatu erosi mountain range menuju pengendapan di sedimentary basin merupakan bagian dari analog konsep difusi. Untuk setiap penambahan waktu $\Delta t$ dan penambahan material sedimen $\Delta S$ yang bergerak dari bagian hulu $S_{A}$ ke hilir lereng $S_{R}$, maka laju perbuahan transportasi material per unit area, yang memiliki dimensi $\left[L^{2} T^{-1}\right]$, adalah:

$$
S_{R}-S_{A}=\Delta S
$$

Dengan menggunakan limit terhadap Persamaan (2) dan mengasumsikan perubahan elevasi hanya akibat erosi dan pengendapan material sedimen, maka persamaan mass continuity untuk mendeskripsikan evolusi landform tersebut adalah:

$$
\Delta H /_{\Delta t}=-\Delta S /_{\Delta r}
$$

Persamaan (3) secara implisit menjelaskan bahwa perbuahan elevasi topografi adalah sebangun dengan adanya perubahan dalam sediment flux $\Delta S_{r}$. 
Persamaan (1) kemudian disubstitusikan kedalam Persamaan (3), sehingga kombinasi tersebut didapat:

$$
\begin{aligned}
& \Delta H / \Delta t=-\Delta\left(-k \frac{\Delta H}{\Delta r}\right) / \Delta r \\
& \Delta H /_{\Delta t}=k \Delta\left(\frac{\Delta H}{\Delta r}\right) /_{\Delta r}
\end{aligned}
$$

dengan menggunakan limit untuk Persamaan (5), $\lim \Delta r \rightarrow d r, \Delta t \rightarrow d t$, maka:

$$
\begin{gathered}
\partial H / \partial t=k \\
\partial H\left(\frac{\partial H}{\partial r}\right) / \partial r \\
\partial t=k^{\partial^{2} H} / \partial r^{2}
\end{gathered}
$$

Persamaan (7) disebut sebagai difusi erosi linear, yang berfungsi sebagai governing equation, dengan $d r$ adalah perubahan kemiringan lereng dan $H$ adalah elevasi topografi permukaan yang bukan variabel bebas. Persamaan (7) juga secara implisit mengindikasikan bahwa perubahan landform terhadap waktu akan proporsional terhadap second derivative curvature-nya. Analog ini sering digunakan pada persamaan konduksi panas dengan $k$ merupakan koefisien termal difusivitas dan $T$ adalah temperatur.

Initial condition pada simulasi ini adalah berupa cekungan simetris yang terbentuk akibat adanya tektonik dengan manifestasi sesar dip-slip berupa fault scarp. Berdasarkan pengamatannya, Hanks dkk. (1984), bentuk lereng curam akibat sesar yang terdegradasi menyerupai fungsi eror (error function/erf.), melalui formulasi sebagai berikut:

$$
H(r, t)=a \cdot \operatorname{erf}[r / 2 \sqrt{(k t)}]+b \cdot r
$$

dengan $H$ adalah elevasi, $r$ adalah dimensi jarak, $t$ adalah waktu, dan $k$ adalah koefisien difusivitas erosi. Koefisien $a$ dan $b$ secara berturut-turut merupakan sudut akibat bidang sesar (fault scarp) dan sudut kemiringan lereng. Gambar 2 menjelaskan representasi koefisien tersebut. Fungsi eror (erf.) membentuk solusi yang mendasar bagi persamaan difusi 1D sebagai initial condition terbentuknya fault scarp dan merupakan pendekatan matematis terhadap evolusi geometri bentuk lahan.

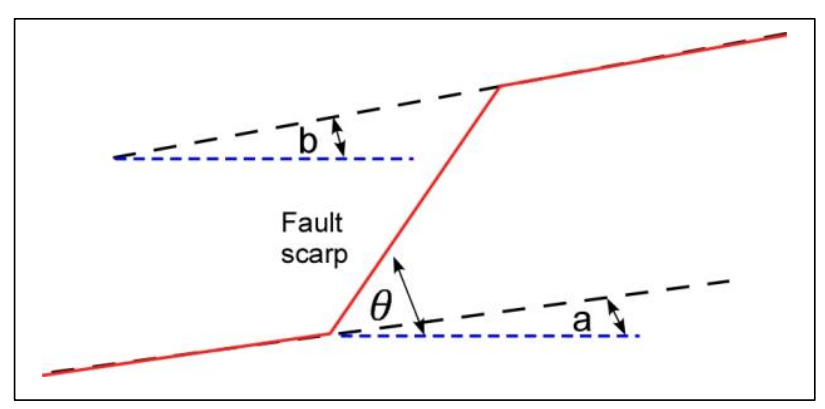

Gambar 2. Keofisien $a$ dan $b$ pada fault scarp

Persamaan (8) merupakan initial condition untuk topografi scarp yang baru terbentuk akibat fault. Hanks dan Andrews (1989) memformulasikan initial condition lainnya untuk kemungkinan kasus alternatif terhadap besaran slope, $\theta$, yang terbentuk akibat degradasi material sedimen sebagai berikut:

$$
\begin{aligned}
H(r, t)=(\theta-b) & \left(\frac{k t}{\pi}\right)^{1 / 2} \cdot\left\{\exp \left(-\frac{[r+a /(\theta-b)]^{2}}{4 k t}\right)\right. \\
& \left.-\exp \left(-\frac{[r-a /(\theta-b)]^{2}}{4 k t}\right)\right\} \\
& +\frac{(\theta-b)}{2}\{(r \\
& \left.+\frac{a}{(\theta-b)}\right) \cdot \operatorname{erf}\left(\frac{r+a /(\theta-b)}{[4 k t]^{1 / 2}}\right) \\
& -(r \\
& \left.\left.+\frac{a}{(\theta-b)}\right) \cdot \operatorname{erf}\left(\frac{r-a /(\theta-b)}{[4 k t]^{1 / 2}}\right)\right\} \\
& +b \cdot r
\end{aligned}
$$

dengan $a, b$, dan $\theta$ adalah parameter besaran sudut. Secara berurut, parameter $a$ dan $b$ adalah sudut yang terbentuk di atas bidang sesar dan di bawah bidang sesar terhadap bidang horizontal atau yang disebut dip angle, sedangkan $\theta$ adalah sudut bidang sesar atau fault scarp (Hackett, 2009).

Solusi difusi linear seperti pada Persamaan (7) dapat dilakukan melalui metode beda hingga. Metode ini merupakan metode numerik yang dapat menyelesaikan permasalahan diferensial parsial secara eksplisit dengan menggunakan bilangan untuk menirukan proses matematik. Banyak permasalahan dalam ilmu terapan, misalnya geologi atau bidang kebumian lainnya, yang bisa dimodelkan 


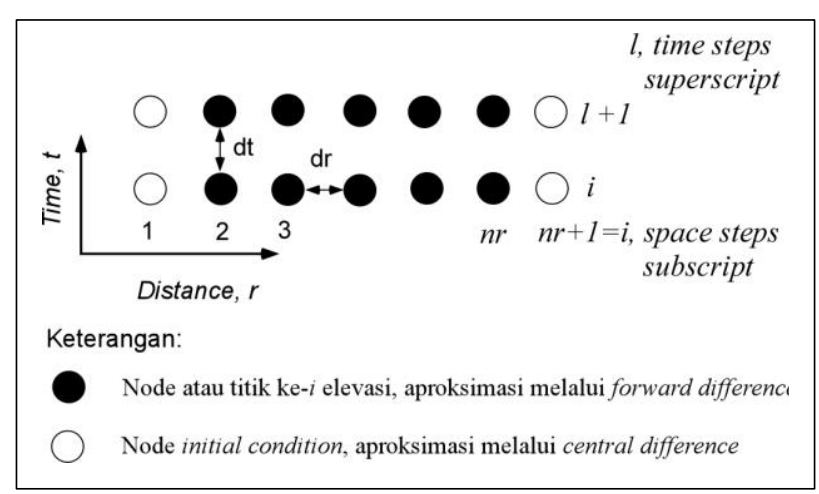

Gambar 3. Skema diskretisasi grid dan geometri

dalam bentuk persamaan diferensial parsial. Metode beda hingga untuk suatu fungsi adalah berdasarkan ekspansi deret Taylor, sehingga persamaan diferensial tersebut dapat diubah dan diselesaikan dengan operasi matematik. Persamaan (7) merupakan diferensial parsial yang memiliki dimensi turunan waktu, $\partial t$, dan turunan ruang, $\partial r$. Gambar 3 merupakan skema diskretisasi time- dan spacederivative yang pemilihannya dapat mempengaruhi hasil model.

Pendekatan beda hingga untuk turnan pertama (time derivatie) dengan forward difference adalah:

$$
\partial H_{\partial t} \approx H_{i}^{l+1}-H_{i}^{l}{ }_{\Delta t}
$$

Kembali ke Persamaan (1), bahwa selisih flux sedimen yang masuk dan yang keluar, $S(r)_{\text {out }}-$ $S(r)_{i n}$, dapat diuraikan menjadi:

$k\left(H_{i+1}^{l}-H_{i}^{l}{ }_{\Delta r}\right)-k\left(H_{i}^{l}-H_{i-1}^{l}{ }_{\Delta r}\right)=$ $k /_{\Delta r^{2}}\left(H_{i+1}^{l}-2 H_{i}^{l}+H_{i-1}^{l}\right)$

dengan mengasumsikan tidak adanya tektonik, maka aproksimasi space derivative dengan menggunakan central difference adalah:

$$
\partial^{2} H / \partial r^{2} \approx k /_{\Delta r^{2}}\left(H_{i+1}^{l}-2 H_{i}^{l}+H_{i-1}^{l}\right)
$$

Kemudian, dengan menyubstitusikan Persamaan (10) dan Persamaan (12) ke Persamaan (7):

$$
H_{i}^{l+1}-H_{i}^{l} /_{\Delta t}=k^{\left(H_{i+1}^{l}-2 H_{i}^{l}+H_{i-1}^{l}\right)} /_{\Delta r^{2}}
$$

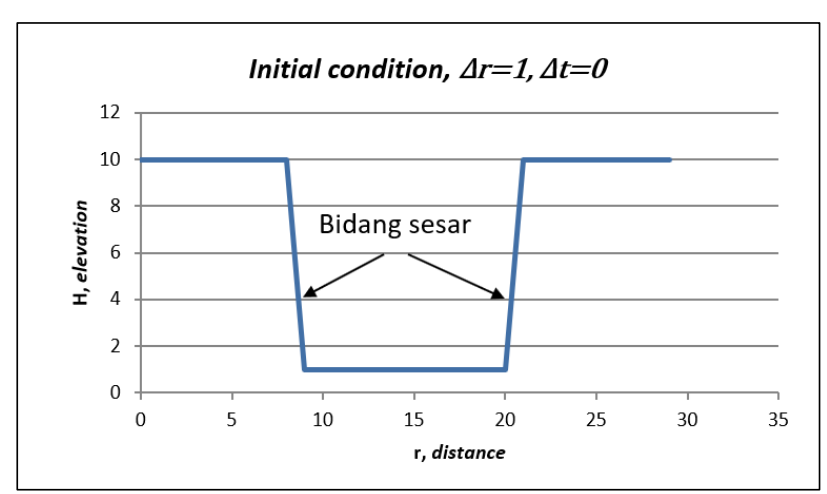

Gambar 4. Fault scarp sebagai initial condition

$H_{i}^{l+1}=H_{i}^{l}+k \Delta t /_{\Delta r^{2}}\left(H_{i+1}^{l}-2 H_{i}^{l}+H_{i-1}^{l}\right)$

$H_{i}^{l+1}=H_{i}^{l}+\lambda\left(H_{i+1}^{l}-2 H_{i}^{l}+H_{i-1}^{l}\right)$

dengan $\lambda=k \Delta t / \Delta r^{2}$. Metode eksplisit ini akan konvergen dan stabil pada syarat $\lambda<1 / 2$ (Ferziger, Joel, 1981). Persamaan (15) merupakan solusi secara eksplisit dari persamaan difusi erosi pada Persamaan (7). Dalam metode eksplisit, aturan transportasi sedimen dan persamaan mass continuity diselesaikan secara berturut-turut dengan nilai $\Delta r$ akan diperbaharui dan diperbaiki terus sesuai dengan nilai $\Delta H$ yang berubah untuk situasi cekungan yang berbeda.

\section{HASIL DAN PEMBAHASAN}

Hasil simulasi difusi erosi didasari pada skenario pemodelan dengan data sintetik dan data lapangan. Skenario tersebut terdiri dari Initial condition, boundary condition, nilai parameter, dan pemenuhan syarat stabilitas. Initial condition merupakan tahapan pembuatan geometri cekungan dengan komponen jarak horizontal dan elevasi $(r, H)$.

Gambar 4 menunjukkan $\Delta t=0$ dan $\Delta r=1$, sesar (fault) baru terbentuk, sehingga topografi pada kedua sisi elevasi (hulu dan hilir) merupakan nilai yang dapat ditentukan secara arbitrer dengan $H_{\max }=10$ dan $H_{\min }=1$ dan membentuk symmetrical fault scarp. Morfologi fault scarp pada kondisi awal pembentukan masih didominasi oleh faktor tektonik dibandingkan erosi dan sedimentasi, sehingga bentuk undulasi permukaan belum tampak. 


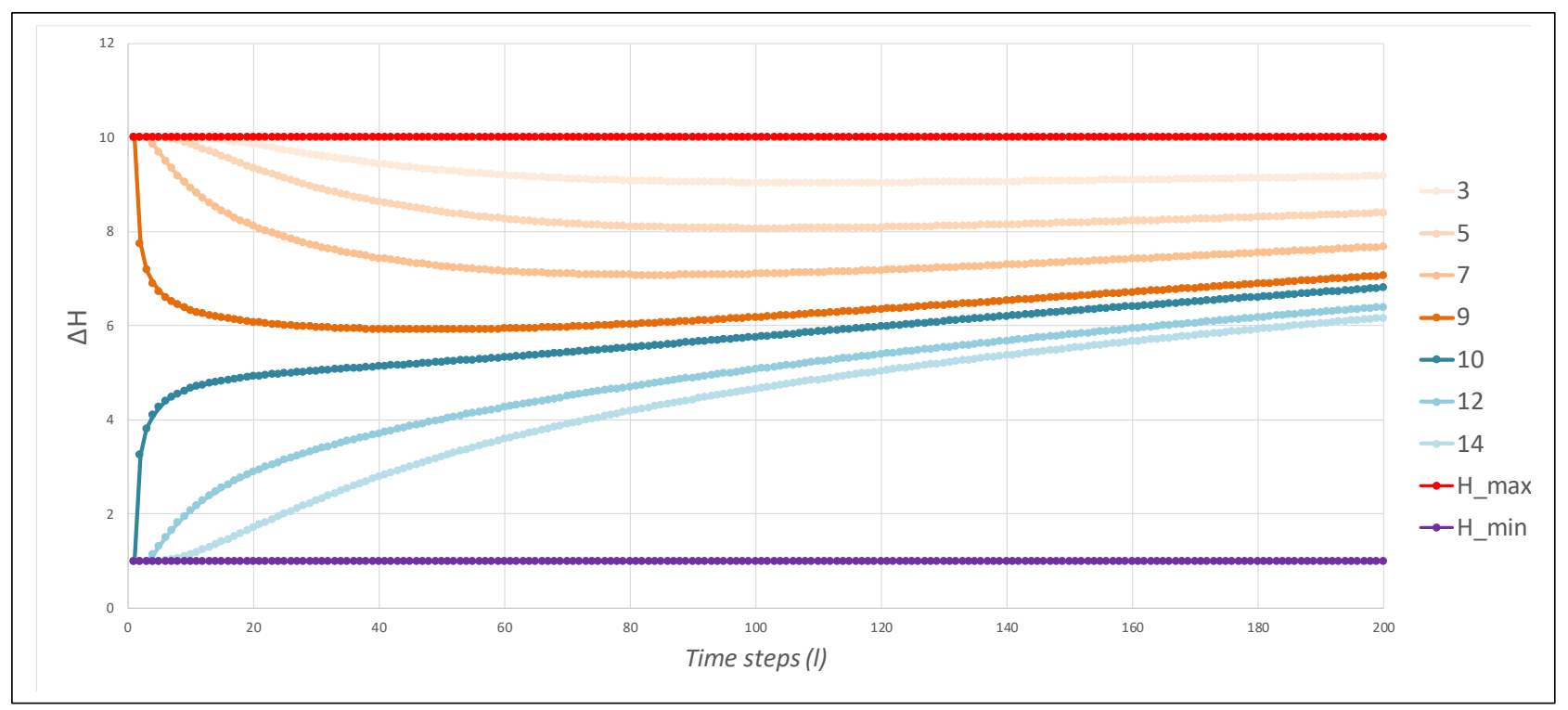

Gambar 5. Perubahan elevasi di titik bagian hulu $(3,5,7,9)$ dan hilir $(10,12,14)$ melaui difusi pada syarat batas

\section{Pengaruh syarat batas pada model difusi}

Untuk kasus transportasi sedimen pada bentang alam fault scarp menggunakan model difusi, erosi hanya akan mengubah atau memodifikasi topografi pada daerah di dekat sesar (fault) tersebut. Oleh karena itu, syarat batas (boundary condition) diambil pada batas elevasi maksimum ( $H_{-}$max) dan minimum (H_min) yang merujuk pada initial condition. Gambar 5 merupakan proses diskretisasi $H_{i}^{l+1}$ menggunakan Persamaan (15) dengan increment time steps (I), secara arbitrer, hingga 200 pada semua titik ruang $i$ sebanyak 30 lokasi pada bagian hulu dan hilir. Sampel lokasi $i$ yang diambil terdiri dari titik 3, 5, 7, 9 dan 10,12, 14. Lokasi 9 dan 10 bertepatan dengan bidang sesar (fault plane), sedangkan semakin menuju lokasi 3 dan 14 semakin jauh dari bidang sesar tersebut. Bagian hulu berada di sepanjang $H_{\max }=10$ dan titik $i$ pada bagian hilir berada di sepanjang $H_{\min }=1$ seperti di Gambar 4 .

Grafik yang ditunjukkan pada Gambar 5 mengindikasikan adanya dua kelompok perubahan elevasi $\Delta H$ secara asimtotik. Kelompok tersebut terbagi kedalam kelompok hulu (ditandai warna merah) dan kelompok hilir (ditandai warna biru) pada Gambar 5. Terlihat pada grafik tersebut bahwa terdapat perubahan elevasi yang tegas (sharp) pada lokasi 9 dan 10 yang merupakan dekat dengan bidang sesar. Sementara itu, perubahan elevasi terlihat bertahap (smooth) pada lokasi lain yang jauh dari bidang sesar seiring dengan bertambahnya increment time steps (I). Di samping itu, perubahan elevasi di bagian hulu secara tegas mengalami penurunan dibandingkan di bagian hilir yang mengalami peningkatan. Kondisi demikian dapat diinterpretasikan sebagai kompensasi terhadap sejumlah sedimen yang tererosi pada bagian hulu dan kemudian terendapkan pada bagian hilir.

\section{Syarat Konvergen dan Stabilitas}

Pada metode numerik, terdapat syarat konvergen yang harus dicapai. Dengan syarat konvergen, $\Delta r, \Delta t \sim 0$, maka aproksimasi dari solusi numerik akan mendekati nilai sebenarnya. Sementara itu, nilai parameter yang diambil dan diasumsikan stasioner adalah:

$$
\begin{aligned}
& \text { 1. } k=1 \mathrm{~m}^{2} / \text { kyear } \\
& \text { 2. } \lambda \leq 0,5
\end{aligned}
$$

Syarat stabilitas, $\lambda$, pada poin ke- 2 tersebut hanya digunakan untuk penyelesaian persamaan difusi secara eksplisit. Jika syarat $\lambda$ tidak terpenuhi, maka akan menghasilkan solusi numerik yang tidak stabil dengan galat yang semakin besar. Untuk memenuhi persyaratan tersebut, maka variasi pemilihan langkah waktu $(\Delta t)$ dan langkah ruang $(\Delta r)$ diusahakan sedemikian rupa agar memenuhi 


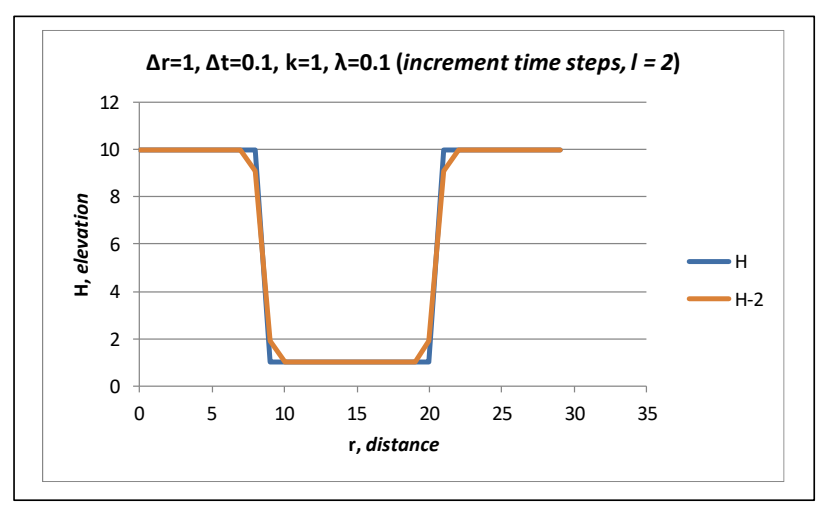

Gambar 6. Solusi numerik dengan $\lambda \leq 0.5$

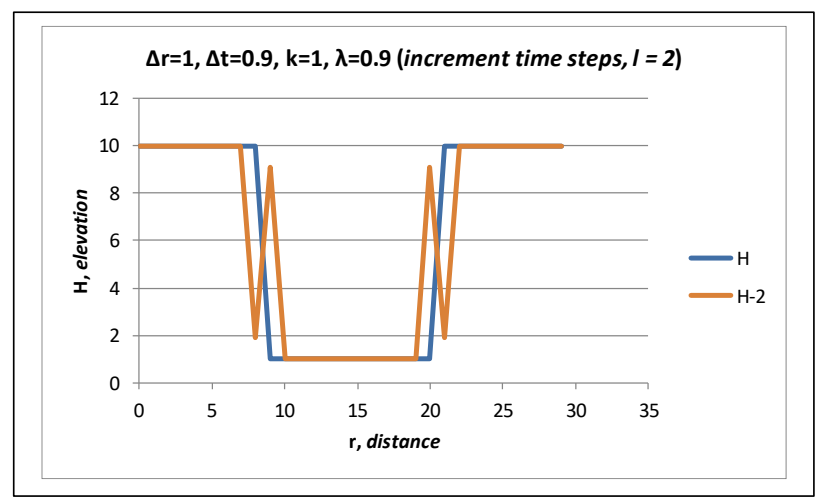

Gambar 7. Solusi numerik dengan tidak memenuhi syarat stabilitas $\lambda \leq 0.5$

$k \frac{\Delta_{t}}{\left(\Delta_{r}\right)^{2}} \leq \frac{1}{2}$. Oleh karena itu, $(\Delta t)$ dan $(\Delta r)$ berpengaruh tehadap nilai lamda $(\lambda)$ yang dihasilkan. Berbeda dengan metode eksplisit, metode implisit menghasilkan nilai yang lebih stabil, sehingga tidak memerlukan syarat stabilitas, tetapi metode ini lebih rumit karena sifat penyelesaiannya yang bersamaan.

Gambar 6 dan Gambar 7 merupakan efek lamda $\lambda$ yang dihasilkan pada solusi numerik. Pada Gambar 6 terlihat adanya aproksimasi pada sampel perubahan elevasi $H_{i}^{2+1}$ yang mendekati initial condition $H_{i}^{1+1}$. Perubahan elevasi mulai terlihat pada zona di sekitar bidang sesar. Sementara itu, Gambar 7 memperlihatkan adanya galat yang cukup besar terhadap aproksimasi yang bahkan menjauhi dari initial condition. Galat tersebut terjadi karena adanya ketidaksesuaian prosedur matematis yang dilakukan, yaitu dengan tidak memenuhi syarat lamda $\lambda$ untuk mendapatkan solusi numerik secara eksplisit. Kesalahan numerik tersebut juga tidak dapat menjelaskan prinsip mass continuity pada persamaan (3), bahwa evolusi bentang alam akibat adanya transportasi sedimen bersifat proporsional terhadap local slope $\left(-\frac{\Delta h}{\Delta r}\right)$. Gambar 7 juga menunjukkan adanya flktuasi perubahan gradien. Perubahan gradien lereng dimungkinkan karena adanya perubahan tektonik. Jika proses ini terjadi, maka asumsi pada Persamaan (2), yaitu perubahan elevasi hanya akibat erosi dan pengendapan material sedimen, tidak terpenuhi.

\section{Pengaruh variasi time steps (I) pada $\mathrm{H}_{i}^{l+1}$}

Pada subab pembahasan ini akan diuji pengaruh varias langkah waktu terhadap perubahan elevasi, dengan mengambil sampel pada titik $3,5,7,9,10$, 12, dan 14 melalui Persamaan (15). Hasil kalkulasi tersaji dalam Tabel 1.

\begin{tabular}{llll}
\multicolumn{4}{l}{ Tabel 1. Variasi $H_{i}^{l+1}$ pada sampel titik $i$} \\
\cline { 1 - 2 } $\boldsymbol{y} \longrightarrow$ & 2 & 5 & 10 \\
\cline { 1 - 2 } $\boldsymbol{i} \downarrow$ & & & \\
\hline 3 & 10 & 10 & 9,999 \\
\hline 5 & 10 & 10 & 9,994 \\
\hline 7 & 10 & 9,970 & 9,733 \\
\hline 9 & 9,1 & 7,691 & 6,898 \\
\hline 10 & 1,9 & 3,308 & 4,101 \\
\hline 12 & 1 & 1,029 & 1,266 \\
\hline 14 & 1 & 1 & 1,005 \\
\hline
\end{tabular}

Tabel 1 memperlihatkan solusi numerik perubahan elevasi sebagai bentuk dari evolusi landform. Perlu diingat kembali bahwa titik ke-i pada lokasi 9 dan 10 dalam Tabel 1 merupakan lokasi yang terdekat dari bidang sesar dengan elevasi maksimum sebesar 10 dan minimum sebesar 1 (tanpa dimensi). Lokasi 9 dan 10 telah mengalami perubahan elevasi (sebesar 9,1 dan 1,9) sejak increment time steps $l=$ 2. Sedangkan titik yang lebih jauh dari bidang sesar $(7,5,3$, dan 12,14$)$ belum mengalami perubahan dari elevasi maksimum maupun minimum. Pada increment berikutnya $(l=5)$, titik 7 dan 12 ikut mengalami perubahan elevasi (sebesar 9,970 dan 1,029). Tahap selanjutnya, yaitu increment $l=10$, 


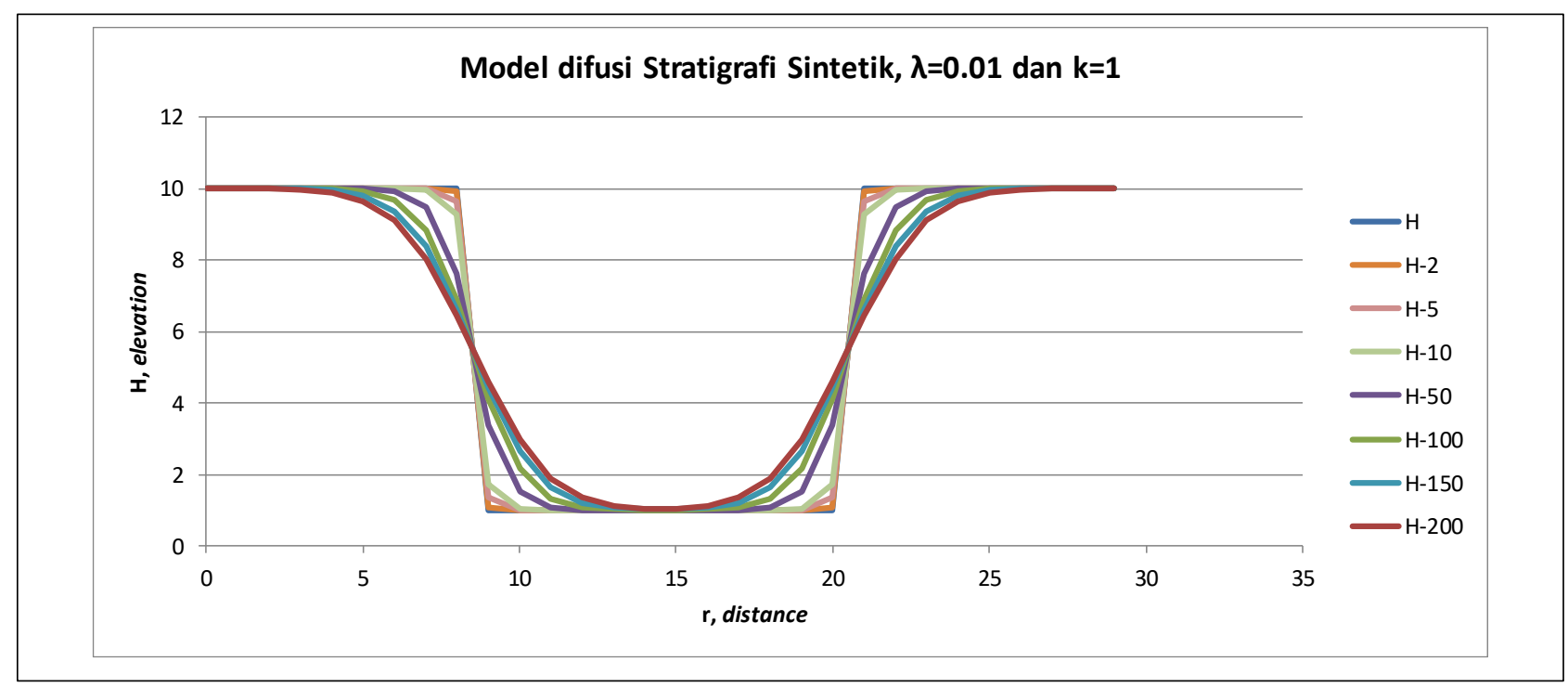

Gambar 8. Evolusi landform $\lambda=0,01$ pada titik increment $\mathrm{H}-2\left(H_{i}^{2+1}\right), \mathrm{H}-5\left(H_{i}^{5+1}\right), \ldots ., \mathrm{H}-200$ $\left(H_{i}^{200+1}\right)$

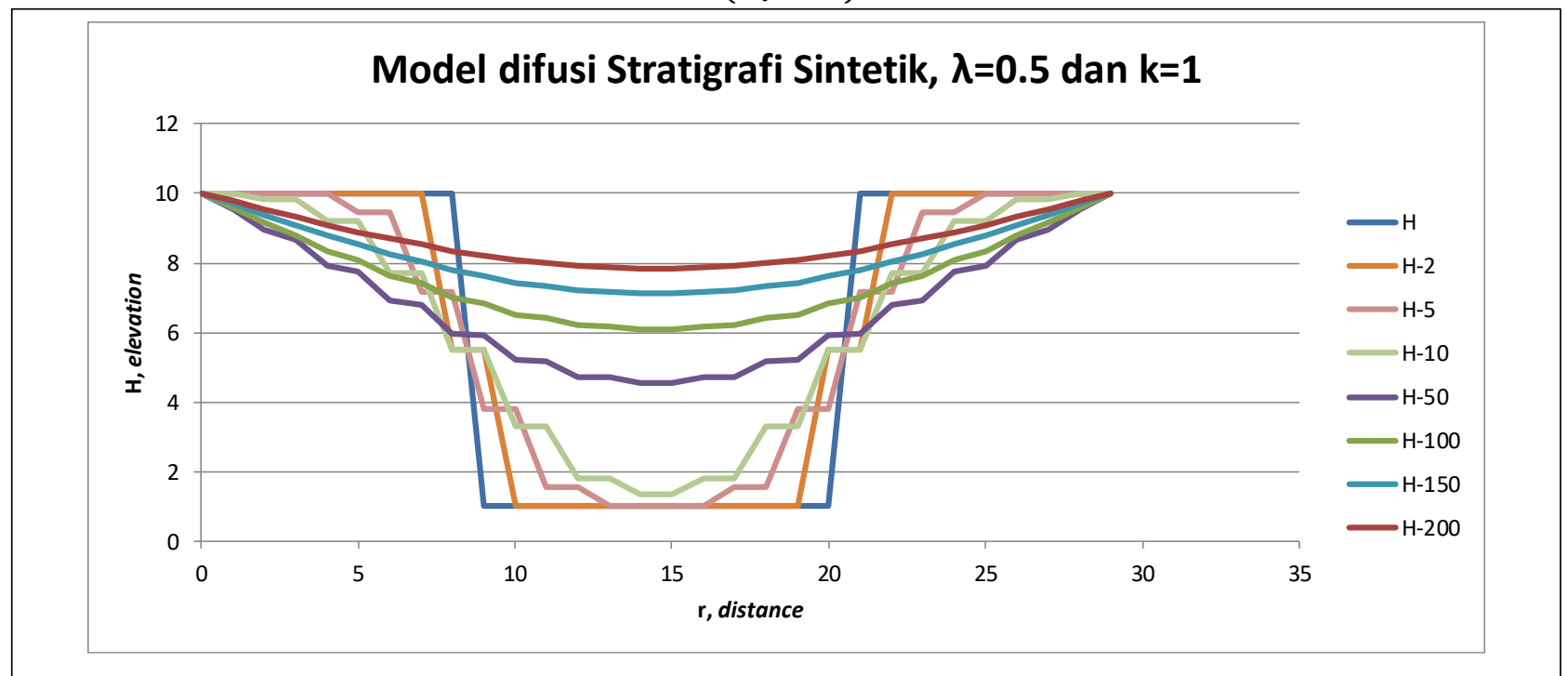

Gambar 9. Evolusi landform $\lambda=0,5$ pada titik increment $\mathrm{H}-2\left(H_{i}^{2+1}\right), \mathrm{H}-5\left(H_{i}^{5+1}\right), \ldots ., \mathrm{H}-200$ $\left(H_{i}^{200+1}\right)$

semua titik telah mengalami perubahan. Evolusi landform terjadi secara bertahap dengan pergerakan menjauhi bidang sesar, seperti yang terlihat pada Gambar 8.

Gambar 8 dan Gambar 9 memperlihatkan model difusi untuk transport sedimen di suatu sistem cekungan berbentuk simetris dan $\lambda$ yang digunakan berbeda tapi tetap memenuhi syarat stabilitas. Perubahan elevasi pada Gambar 8 terlihat lebih smooth dibandingkan perubahan elevasi pada Gambar 9 yang lebih tajam (sharp). Semakin lama interval waktu yang diperlukan untuk suatu material sedimen tererosi dan terendapkan, maka evolusi bentang alam akan semakin membentuk undulasi. Sedangkan jika perubahan elevasi (akibat erosi dan pengendapan) terjadi dalam interval waktu yang singkat, maka evolusi bentang alam akan tidak akan berubah terlalu jauh dari morfologi asalnya.

Perubahan bentuk morfologi fault scarp pada model difusi tersebut merupakan fungsi waktu karena proses erosi yang dimodelkan menggunakan persamaan difusi. Sejumlah massa pada topografi 


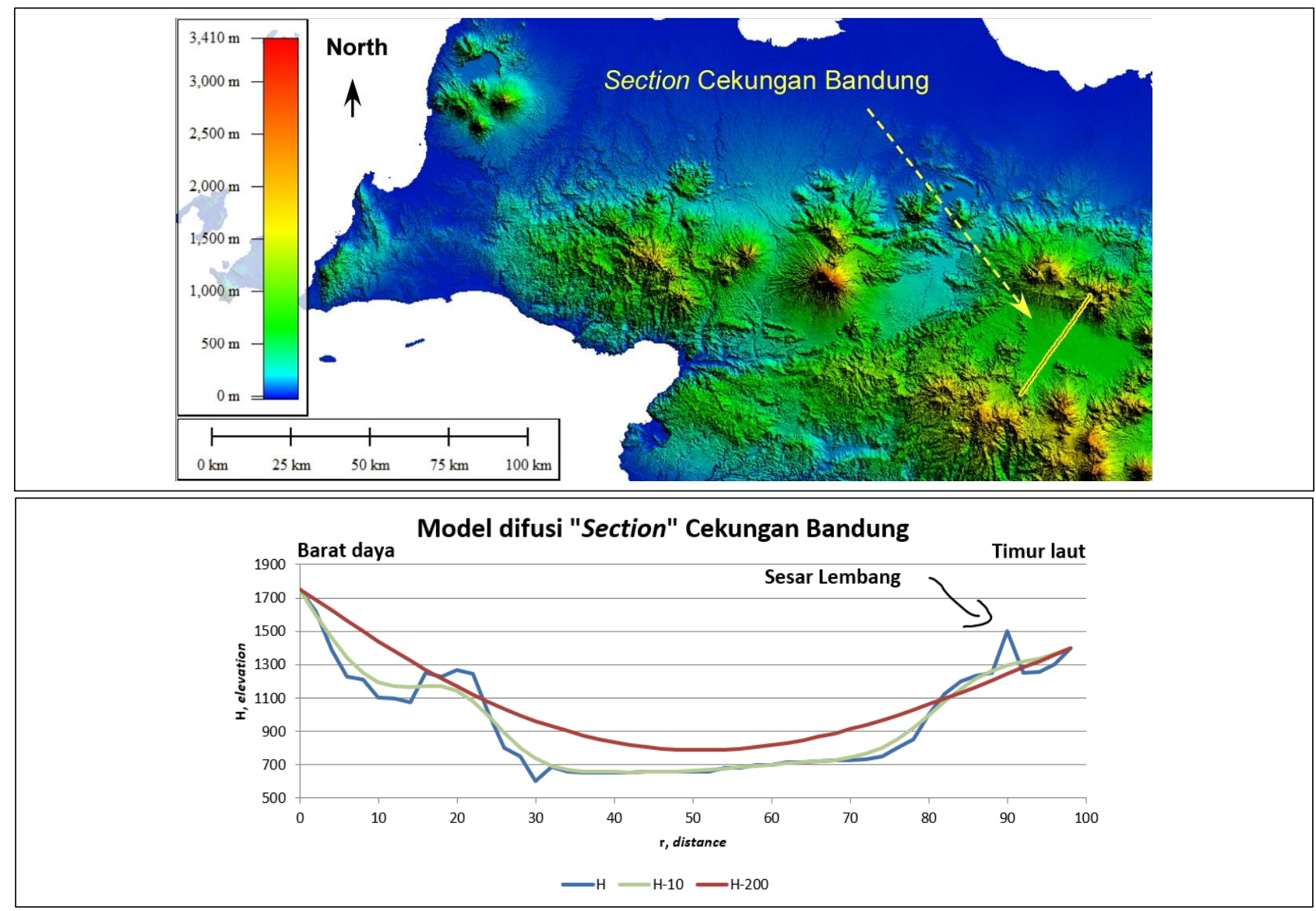

Gambar 10. Model difusi pada Cekungan Bandung

tertentu akan tererosi dari suatu blok yang terangkat (uplifted block) dan bergerak secara difusi dari daerah hulu ke daerah hilir (down block).

Nilai koefisien difusi $(k)$ memiliki dimensi yang melekat pada ruang $\Delta r$ dan waktu $\Delta \mathrm{t}$. Dalam proses terbentuknya suatu morfologi sesar (fault scarp), tentunya akan melibatkan batuan yang terdeformasi. Ketika batuan tersebut tersingkap ke permukaan akibat proses tektonik dalam bentuk sesar, maka interaksi dengan permukaan (surface process) akan menghasilkan erosi yang mampu mengikis batuan tersebut seiring dengan berjalannya waktu. Dengan kata lain, nilai keofisien difusi bergantung pada tipe batuan yang tersesarkan (yang menempati suatu ruang $\Delta x$ ) dan proses-proses permukaan (yang berjalan seiring dengan waktu $\Delta t$ ).

Gambar 10 merupakan penerapan model difusi pada data riil dengan adanya morfologi sesar di bagian Sesar Lembang. Cekungan Bandung muncul setelah erupsi Gunung Sunda, sekitar 55000 tahun yang lalu, dan berbatasan dengan Cekungan antar- busur pegunungan (Leles-Garut Intra-Arc Basin) di bagian tenggara (Haryanto dkk., 2018; Tarigan dkk., 2016). Saat increment time-steps masih rendah ( $\mathrm{H}-$ 10), maka perubahan elevasi $(\mathrm{H})$ belum terlalu besar. Sebaliknya, perubahan elevasi saat berada di posisi increment $\mathrm{H}-200$ menunjukkan perubahan elevasi yang cukup signifikan. Berdasarkan data lapangan dan yang telah disimulasikan melalui model difusi tersebut, erosi yang terus menerus terjadi seiring berjalannya waktu akan menghasilkan pengendapan sedimen yang tebal ke arah cekungan.

\section{PENUTUP}

\section{Simpulan dan Saran}

Simulasi menggunakan persamaan difusi telah memberikan gambaran mekanisme perpindahan partikel sedimen di suatu cekungan. Syarat stabilitas $\lambda$ pada metode eksplisit menjadi parameter yang mutlak harus terpenuhi agar tidak terjadi galat aproksimasi yang terlalu besar pada solusi numerik. Stratigrafi sintetik yang dibuat 
menggunakan difusi linear, artinya evolusi urutan waktu erosi dan pengendapan tidak disertai dengan adanya perubahan tektonik pada saat bersamaan yang mengakibatkan adanya fluktuasi gradien atau lereng sebagai jalur transportasi sedimen. Jika terdapat fluktuasi perubahan gradien, maka aproksimasi melalui solusi numerik akan menghasilkan galat yang besar dan menghasilkan solusi yang tidak mendekati keadaan ideal. Perubahan-perubahan landform akan diawali pada zona-zona bidang sesar berdasarkan model difusi dan disusul pada zona-zona yang menjauhi bidang sesar.

Selain data sintetik, makalah ini juga menyimulasikan proses stratigrafi dari runtutan peristiwa erosi dan pengendapan pada morfologi Cekungan Bandung. Pergerakan material sedimen dapat terlihat melalui model difusi yang berpindah dari suatu elevasi tertentu di hulu menuju bagian yang lebih rendah di hilir. Nilai koefisien difusi juga diduga memiliki peran secara geologi, yaitu tipe batuan serta proses erosi yang berlangsung. Penelitian selanjutnya terbuka peluang untuk mengetahui pengaruh ketahanan batuan terhadap tingkat erosi yang terjadi pada zona-zona sesar misalnya, sehingga koefisien difusi untuk masingmasing kondisi geologi dapat dikarakterisasikan dengan kondisi riil lapangannya.

\section{Ucapan Terima Kasih}

Penulis mengucapkan terima kasih kepada segenap rekan di Laboratorium Stratigrafi, Program Studi Teknik Geologi, Fakultas Teknik Geologi Universitas Padjadjaran atas diskusi dan masukannya.

\section{DAFTAR PUSTAKA}

Alam, S., \& Setiadi, D. J. (2019). Tertiary sequence stratigraphy of Bird Head Area, Eastern Indonesia. Indonesian Journal on Geoscience2, 6(3), 267-278. https://doi.org/DOI: 10.17014/ijog.6.3.267-278

Atkinson, C., Renolds, M., \& Hutapea, O. (2006). Stratigraphic traps in the Tertiary rift basins of Indonesia: case studies and future potential. The Geological Society of London, 254, 105-126. https://doi.org/https://doi.org/10.1144/GSL.SP.20
06.254.01.06

Brush, L. (1962). Exploratory study of sediment diffusion. Journal of Geophysical Research, 67(4), 1427-1433.

Cloetingh, S., \& Burov, E. (2011). Lithospheric folding and sedimentary basin evolution: a review and analysis of formation mechanisms. Basin Research, 23, 257290.

https://doi.org/https://doi.org/10.1111/j.13652117.2010.00490.x

Ferziger, Joel, H. (1981). Numerical methods in engineering application. John Wiley \& Sons, Inc.

Granjeon, D, \& Phillip, J. (1999). Concepts and applications of a 3-D multiple lithology, diffusive model in stratigraphic modeling. SEPM (Society for Sedimentary Geology), 62, 197-210.

Granjeon, Didier. (2014). 3D forward modelling of the impact of sediment transport and base level cycles on continental margins and incised valleys. Int. Assoc. Sedimentol. Spec. Publ., 46, 453-472.

Hackett, W. R. (2009). Paleoseismology. In Paleoseismology (p. 193).

Hanks, T. C., \& Andrews, D. J. (1989). Effects of far-field slope on morphologic dating of scarplike landforms. Journal of Geophysical Research, 94, 565-573.

Hanks, T. C., Bucknam, R. C., Lajoie, K. R., \& Wallace, R. E. (1984). Modification of wave-cut and faultingcontrolled landforms. Journal of Geophysical Research, 89, 5771-5790.

Haryanto, I., Setiadi, D., Alam, S., IImi, N., \& Sunardi, E. (2018). Mountain-front sinuosity and asymmetrical factor of Leles-Gary Intra-Arc Basin, West Java. Journal of Geological Sciences and Applied Geology, 2(5), 1-8.

Hawie, N., Covault, J., \& Sylvester, Z. (2019). Grain-Size and Discharge Controls on Submarine-Fan Depositional Patterns From Forward Stratigraphic Models. Frontiers in Earth Science, 7(334), 1-15. https://doi.org/https://doi.org/10.3389/feart.2019 .00334

Kaufman, P., J.P., G., \& D.S., M. (1991). Depth-dependent diffusion algorithm for simulation of sedimentation in shallow marine depositional systems. Kansas Geological Survey, 233, 489-508.

Muchlis, \& Elders, C. (2020). Structural style of the North Sumatra basin, offshore Aceh. IOP Converence Series: Materials Science and Engineering, 1-6. https://doi.org/doi:10.1088/1757899X/796/1/012038

Nayoan, G. A. . (1981). Offshore hydrocarbon potential of 
Indonesia. Pergamon Press Ltd, 6(11), 1225-1246.

https://doi.org/https://doi.org/10.1016/0360-

5442(81)90034-7

Noda, A. (2013). Strike-Slip Basin - Its Configuration and Sedimentary Facies. In Mechanism of Sedimentary Basin Formation - Multidisciplinary Approach on Active Plate Margins (pp. 27-56). https://doi.org/DOI: 10.5772/56593

Paola, C., \& Voller, R. (2005). A generalized Exner equation for sediment mass balance. Journal of Geophysical Research, 110, 1-8.

Rivenaes, J. C. (1992). Application of a dual-lithology, depth-dependent diffusion equation in stratigraphic simulation. Basin Research, 4, 133146.

Schwarzacher, W. (1975). Sedimentation Models and Quantitative Stratigraphy. Elsevier Scientific Publishing.

Stirling, E., Fugelli, E., \& Thompson, M. (2017). The edges of the wedges: a systematic approach to trap definition and risking for stratigraphic, combination and sub-unconformity traps. Geological Society of London: Lyell Collection, 8, 273-286. https://doi.org/https://doi.org/10.1144/PGC8.19

Suwondo, Haris, A., \& Wiyono, R. (2019). Sandstone Reservoir Distribution Mapping of Bekasap Formation using Seismic Attributes and Identification of Stratigraphic Trap in " $X$ " Field, Central Sumatera Basin. IOP Converence Series: Materials Science and Engineering, 1-8. https://doi.org/doi:10.1088/1757899X/546/7/072009

Tarigan, A., Sagala, S., Samsura, A., Fiisabiilillah, D., Simarmata, H., \& Nababan, M. (2016). Bandung City, Indonesia. Cities, 50, 100-110. https://doi.org/DOI: 10.1016/j.cities.2015.09.005

Zanella, E., \& Collard, J. (2017). Are Stratigraphic Traps More Risky? Conference: AAPG/SEG International Conference and Exhibition. 